\title{
Epiphytic bacterial production on Zostera marina
}

\author{
David L. Kirchman ${ }^{1 *}$, Lucia Mazzella ${ }^{2}$, Randall S. Alberte ${ }^{3}$ and Ralph Mitchell ${ }^{1}$ \\ 1 Division of Applied Sciences, Harvard University, 40 Oxford Street, Cambridge, Massachusetts 02138, USA \\ 2 Department of Benthos Ecology, Zoological Station Naples, Ischia, Italy \\ ${ }^{3}$ Barnes Laboratory, The University of Chicago, 5630 S. Ingleside Avenue, Chicago, Illinois 60637, USA
}

\begin{abstract}
This study tested if epiphytic bacteria on Zostera marina L. (eelgrass) could obtain sufficient organic carbon from leaf photosynthesis to support their production. When individual $Z$. marina leaves were placed with tips in dark chambers and bases in illuminated chambers and sodium ${ }^{14} \mathrm{C}$-bicarbonate was injected into the illuminated chambers, radioactivity appeared in the dark. chambers only by translocation through the leaves. The flux of organic carbon from $Z$. marina to the bacteria was approximately $0.3 \mu \mathrm{gC} \mathrm{h} \mathrm{h}^{-1} \mathrm{~cm}^{-2}$ while the highest bacterial production, based on ${ }^{3} \mathrm{H}$ thymidine incorporation rates, was $0.4 \mu \mathrm{gC} \mathrm{h}^{-1} \mathrm{~cm}^{-2}$. DOC excretion rates from $Z$. manina leaves were approximately $2 \%$ of total carbon fixation. Bacterial abundance and ${ }^{3} \mathrm{H}$-thymidine incorporation rates increased significantly from the bases to tips of the leaves. These data demonstrate that the epiphytic bacterial population is supported almost entirely by carbon obtained directly from $Z$. marina photosynthesis.
\end{abstract}

\section{INTRODUCTION}

Seagrass ecosystems of temperate and high latitudes of the Northern Hemisphere are dominated by Zostera marina L. (eelgrass). Z. marina beds are among the most productive plant stands in the world (Phillips and McRoy, 1980) with net primary productivity estimates of 0.2 to $1.0 \mathrm{mg} \mathrm{C} \mathrm{g}^{-1}$ (dry) wt $\mathrm{h}^{-1}$ (McRoy and McMillan, 1977) which when extrapolated to an areal basis, approach $4.0 \mathrm{~g} \mathrm{C} \mathrm{m}^{-2} \mathrm{~d}^{-1}$. The presence of a diverse epiphytic community of primary producers (e. g. unicellular and macrophytic algae), bacteria, protozoans and such invertebrates as byrozoans and spirorbid polychaetes (Harlin, 1980) also contributes significantly to the total productivity of eelgrass communities (McRoy and McMillan, 1977; Penhale, 1977).

Several investigators (McRoy and Goering, 1974; Harlin, 1980; Penhale and Thayer, 1980) have demonstrated that the microbial epiphytes of Zostera marina obtain organic carbon, phosphorous, and nitrogenous compounds from the leaves of this seagrass. This suggests that significant and perhaps requisite relationships exist between certain heterotrophic epiphytic species and Z. marina. Smith and Penhale (1980) showed that epiphytic heterotrophs on $Z$. marina leaves incorporated dissolved organic carbon (DOC)

- Present address: Dr David Kirchman, Department of Microbiology, University of Georgia, Athens, Georgia 30602, USA

(C) Inter-Research/Printed in F. R. Germany derived from the leaves. However, because of the design of this study it is not possible to ascertain whether the $\mathrm{DO}{ }^{14} \mathrm{C}$ collected was derived solely from eelgrass leaf metabolism or from metabolism of leaf epiphytes, or both. In a similar study, Penhale and Thayer (1980) found ${ }^{14} \mathrm{C}$-radioactivity in the epiphytes of $Z$. marina when the plant was illuminated and exposed to ${ }^{14} \mathrm{CO}_{2}$. However, it is possible that epiphytic algae incorporated ${ }^{14} \mathrm{CO}_{2}$ that had been respired by the $Z$. marina leaves, which would be interpreted erroneously as heterotrophic activity.

In the present study we sought to determine whether DOC excretion by Zostera marina leaves could support the epiphytic bacterial production on the leaf surfaces of this seagrass. The amount of organic carbon released by the eelgrass was estimated using an experimental design that eliminated epiphytic algal contributions and measured DOC incorporation directly into epiphytic microheterotrophs. This study also estimated epiphytic bacterial production, using the incorporation of $\left({ }^{3} \mathrm{H}\right.$-methyl)-thymidine, on $Z$. marina leaves.

\section{MATERIALS AND METHODS}

\section{Collection of Zostera marina}

Leaves of Zostera marina L. were collected at a 1 to $2 \mathrm{~m}$ depth in Great Harbor, Woods Hole, MA (USA) 
during July and August 1980. The freshly collected leaves used in these experiments were approximately $50 \mathrm{~cm}$ long and possessed no invertebrate or macroalgal colonization.

\section{Transfer of photosynthate to epiphytic heterotrophs}

To test whether epiphytic heterotrophs assimilate organic carbon from Zostera marina, individual eelgrass leaves were placed with tips in dark chambers and bases in illuminated chambers (Fig. 1). Both chambers were filled with filtered (0.22 $\mu \mathrm{m}$ Millipore) seawater, and damp tissue paper was draped over the section of $Z$. marina not contained in a chamber. $\mathrm{NaH}^{14} \mathrm{CO}_{3}$ (ca. $5 \mu \mathrm{Ci}$ ) was injected into the illuminated

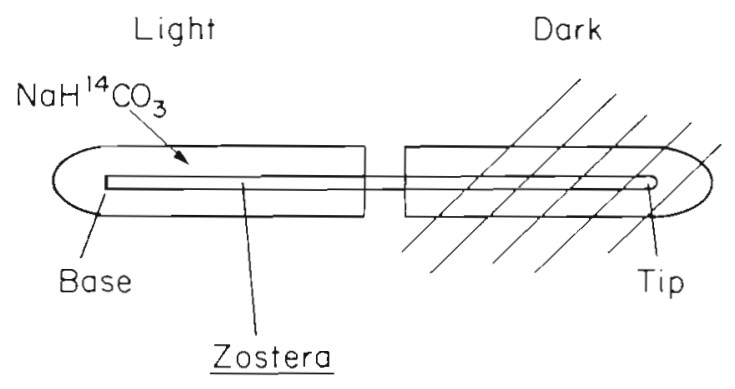

Fig. 1. Experimental design employed in order to distinguish between phototrophic and heterotrophic epiphytic communities. The volume of each chamber was $50 \mathrm{ml}$

chamber and the leaf blades were incubated for $4 \mathrm{~h}$ at approximately $25^{\circ} \mathrm{C}$. The photon flux density at the leaf surface was approximately $125 \mu \mathrm{mol}$ quanta $\mathrm{s}^{-1}$ $\mathrm{m}^{-2}$ (PAR), a level which is above saturation for photosynthesis of $Z$. marina (Mazzella et al., 1980).

The movement of ${ }^{14} \mathrm{C}$ from leaf bases to the tips was followed by measuring the appearance of radioactivity in the Zostera marina leaves and epiphytes and as ${ }^{14} \mathrm{CO}_{2}$ and $\mathrm{DO}^{14} \mathrm{C}$. After incubation, the leaf blades were cut at the region between the 2 chambers and washed with $\mathrm{NaHCO}_{3}(0.1 \mathrm{M})$. Leaf sections $(1.0 \times 0.5 \mathrm{~cm})$ of eelgrass containing epiphytes were put into $1 \mathrm{ml}$ of Protosol (New England Nuclear). The remaining sections were stripped of epiphytes by scraping the leaves with a razor blade. The razor blade was wiped with filter paper which was put into $1 \mathrm{ml}$ of Protosol as were the leaf sections of the scraped $Z$. marina $(1.0 \times 0.5 \mathrm{~cm})$. The samples were incubated for approximately $16 \mathrm{~h}$ at $50^{\circ} \mathrm{C}$ to digest the plant material followed by the addition of Econofluor (New England Nuclear) when the sample had cooled.

The seawater in both chambers was sampled for both ${ }^{14} \mathrm{CO}_{2}$ and $\mathrm{DO}^{14} \mathrm{C}$ by transferring the seawater into flasks with serum caps. The water was acifidied with
$\mathrm{H}_{2} \mathrm{SO}_{4}$ and incubated for $1 \mathrm{~h}$ on a rotary table to trap the ${ }^{14} \mathrm{CO}_{2}$ (Hobbie and Crawford, 1969). After incubation the phenethylamine-soaked filter paper trap was put into $10 \mathrm{ml}$ of Aquasol-2 (New England Nuclear). The acidified seawater $(5 \mathrm{ml})$ was added also to $10 \mathrm{ml}$ of Aquasol for determination of $\mathrm{DO}^{14} \mathrm{C}$.

The efficiency of removing and recovering the epiphytic heterotrophs by scraping was approximately $80 \%(\bar{s}=20 \% ; n=5)$ and $91 \%(\bar{s}=15 \% ; n=5)$, respectively. This was estimated by incubating blades of Zostera marina in filtered ( $0.22 \mu \mathrm{m}$ Millipore) seawater with ${ }^{14} \mathrm{C}$-glucose for $4 \mathrm{~h}$ in the dark. The epiphytes were scraped off the eelgrass as described above. The efficiency of removing and recovering the epiphytes was calculated by comparing the radioactivity of the unscraped eelgrass with the scraped eelgrass and epiphytes, respectively. The large variation in our calculated efficiency is due principally to naturally large variation (an order of magnitude) in the epiphytic bacterial populations as shown in this paper.

The efficiency of removing and recovering the ${ }^{14} \mathrm{CO}_{2}$ was 99.9 and $90.9 \%$, respectively. This efficiency was calculated by adding $\mathrm{NaH}^{14} \mathrm{CO}_{3}$ to the plant chamber (Fig. 1) containing filtered seawater. A sample of the water was removed and acidified as described above. The efficiency of recovering ${ }^{14} \mathrm{C}$-carbon from both the light and dark chambers was $90 \%(\overline{\mathrm{s}}=10 \% ; \mathrm{n}=6)$.

\section{Bacterial abundance, biomass and production}

Bacterial abundance, biomass and production were estimated on leaf sections of Zostera marina washed with filtered seawater. Leaf base and tip sections were located $5 \mathrm{~cm}$ from the rhizomes and apical tip, respectively, while a middle section was also examined. In order to determine bacterial abundance, two $1 \mathrm{~cm}$ slices from each leaf section were preserved in $2 \%$ (v/ v) formaldehyde solution made with filtered seawater.

Bacterial production was estimated from the rate of DNA synthesis measured by the incorporation of $\left({ }^{3} \mathrm{H}\right.$ methyl) thymidine (Fuhrman and Azam, 1980). Leaf sections $(1 \times 0.5 \mathrm{~cm})$ were incubated in $5 \mathrm{nM}\left({ }^{3} \mathrm{H}\right.$ methyl) thymidine (64 $\mathrm{Ci}$ mmole ${ }^{-1}$; New England Nuclear) in $10 \mathrm{ml}$ of filtered (0.22 $\mu \mathrm{m}$ Millipore) seawater at the same temperature and light intensity as described above. After $1 \mathrm{~h}$, the leaf sections were extracted in $5 \mathrm{ml} 0$ to $4{ }^{\circ} \mathrm{C}$ trichloroacetic acid (TCA) for $30 \mathrm{~min}$ and then the TCA was filtered through $0.45 \mu \mathrm{m}$ Millipore filters. Filters and leaf sections were rinsed twice with ice-cold TCA. TCA-insoluble compounds on leaf sections and filters were hydrolyzed with $0.5 \mathrm{ml}$ of $1.0 \mathrm{~N} \mathrm{HCl}$ by placing the samples in a $100^{\circ} \mathrm{C}$ water bath for $30 \mathrm{~min}$. After the sample had cooled, $10 \mathrm{ml}$ of Aquasol-2 was added. The efficiency 
of counting was determined by the external channels ratio method. Radioactivity on the filters was approximately $10 \%$ of the total activity remaining on the leaves. Controls for abiotic adsorption of ${ }^{3} \mathrm{H}$-thymidine were prepared as described above, but $0.5 \mathrm{ml}$ of formalin was added. Abiotic adsorption was less than $5 \%$ of the lowest rate of biotic uptake.

Bacterial numbers were determined by the acridine orange direct count method (Hobbie et al., 1977). Preserved leaf sections were ground manually in $2 \mathrm{ml}$ of filtered seawater in a tissue homogenizer. After allowing the homogenate to settle overnight, small subsamples $(0.2$ or $0.4 \mathrm{ml})$ were added to $2 \mathrm{ml}$ of acridine orange in filtered seawater. The final concentration of stain was $0.01 \%(\mathrm{w} / \mathrm{v})$. Subsamples were stained for $2 \mathrm{~min}$ and then filtered through $0.2 \mu \mathrm{m}$ Nuclepore filters, prestained with irgalan black. Ten fields with at least 30 bacteria per field were counted for each sample. The number of bacteria in the filtered seawater and stain was less than $1 \%$ of the lowest sample count. We have no estimate on how many bacteria settled. However, because samples filtered through a $10 \mu \mathrm{m}$ Nuclepore filter were also difficult to count, the homogenization procedure appeared to be thorough and sufficient.

The biomass of epiphytic bacteria was estimated by measuring bacterial cell sizes with an ocular micrometer. Twenty-five bacteria were measured for each sample (125 bacteria per leaf section) and were categorized into either spheres or cylinders. Cell volumes were converted to biomass using $1.21 \times 10^{-7}$ $\mu \mathrm{gC} \mu \mathrm{m}^{-3}$ (Watson et al., 1977).

The statistical tests used here, all of which were nonparametric, are described by Sokal and Rohlf (1969) with the exception of Jonchkeere's test. Hollander and Wolfe (1973) explain the use of Jonchkeere's test for ordered alternatives.

\section{RESULTS}

\section{Uptake of organic carbon by epiphytic heterotrophs}

This study tested whether epiphytic microheterotrophs could obtain organic carbon from Zostera marina photosynthesis by monitoring the appearance of ${ }^{14} \mathrm{C}$-labeled compounds in the dark-chamber epiphytes. The absolute amount of radioactivity in the epiphytes was usually about 3 times background levels (Table 1). Radioactivity in the dark-chamber epiphytes appears to result from epiphytic heterotrophic uptake of organic carbon synthesized by the leaf in the illuminated chamber and translocated to the dark chamber.

Three different controls were performed in order to discount radioactivity from leaves injured while
Table $1 .{ }^{14} \mathrm{C}$-Radioactivity recovered in epiphytes (dark chamber) of Zostera marina. Background level (69 dpm median) was estimated from a leaf section not exposed to $\mathrm{NaH}^{14} \mathrm{CO}_{3}$

\begin{tabular}{|c|c|c|c|}
\hline \multirow[t]{2}{*}{ Treatment } & \multicolumn{3}{|c|}{${ }^{14} \mathrm{C}$-Radioactivity (DPM) } \\
\hline & Median & Range & $\mathrm{N}$ \\
\hline Untreated & 1000 & $98-1700$ & 6 \\
\hline Pre-scraped ${ }^{\dagger}$ & 20 & $19-69$ & 3 \\
\hline Formalin-killed & 103 & - & 1 \\
\hline Dark ${ }^{14} \mathrm{CO}_{2}$-fixation & 23 & - & 1 \\
\hline \multicolumn{4}{|c|}{$\begin{array}{l}\text { 'Pre-scraped' refers to leaves scraped clean of epiphytes } \\
\text { before exposure to } \mathrm{NaH}^{14} \mathrm{CO}_{3} \\
\text { - See text for how radioactivity resulting from dark }{ }^{14} \mathrm{CO}_{2} \text { - } \\
\text { fixation was estimated }\end{array}$} \\
\hline
\end{tabular}

removing the epiphytes, contamination by ${ }^{14} \mathrm{CO}_{2}$, dark ${ }^{14} \mathrm{CO}_{2}$ fixation, and abiotic adsorption. First, leaves were scraped with a razor blade to remove the epiphytes and the experiment was repeated as described. Scraping the leaves before incubation in the ${ }^{14} \mathrm{CO}_{2}$ reduced significantly the radioactivity in darkchamber epiphytes ( $p<0.05$; Mann-Whitney U Test) (Table 1), which confirmed that the presence of the dark-chamber epiphytes was necessary for radioactivity to appear in the compartment labeled 'darkchamber epiphytes'. Thus, these results indicate that the radioactivity in the dark chamber epiphytes was not due to ${ }^{14} \mathrm{C}$-carbon traveling along an unstirred layer of water on the eelgrass leaf surfaces from the illuminated to the dark chamber, nor is it from removal of leaf fragments when the leaf is scraped. Scraping the leaves before incubation did not significantly alter the rate of leaf photosynthesis $\left(3.5 \mu \mathrm{gC} \mathrm{h}^{-1} \mathrm{~cm}^{-2}\right.$ for controls and scraped; standard error (S. E.) $=0.9 \mu \mathrm{gC}$ $\mathrm{h}^{-1} \mathrm{~cm}^{-2}$ ) nor the percent of ${ }^{14} \mathrm{C}$-carbon translocated from the illuminated to the dark chamber $(0.5 \%$; S. E. $=0.2 \%$ ). Further, microscopic examination of the leaves revealed no visible damage to the leaves due to scraping. The second control experiment provided additional evidence that the radioactivity in the darkchamber epiphytes was not due to contamination. A leaf blade was first killed in $2 \%(\mathrm{v} / \mathrm{v})$ formaldehyde solution and then used in the experiment described earlier. The radioactivity sampled in the dark-chamber epiphytes was not significantly above background (Table 1).

It could be argued that radioactivity in the darkchamber epiphytes resulted from carbon that had been respired by Zostera marina and subsequently fixed by the epiphytes, i.e. the radioactivity did not result from uptake of $\mathrm{DO}^{14} \mathrm{C}$ by the epiphytes but from dark $\mathrm{CO}_{2}$ fixation. In order to discount this alternative hypothesis, we calculated in a third control experiment the 
maximum amount of radioactivity that could have appeared in the dark-chamber epiphytes because of dark $\mathrm{CO}_{2}$ fixation. For the worst possible case, the highest dark ${ }^{14} \mathrm{CO}_{2}$ fixation rate we measured $\left(0.011 \mu \mathrm{gC} \mathrm{h}^{-1} \mathrm{~cm}^{-2}\right)$ was used in our calculations, and we assumed that all of the radioactivity in the dark chamber appeared first as ${ }^{14} \mathrm{CO}_{2}$. Based on these unrealistic assumptions which maximize dark fixation, only 23 DPM's could have been due to dark fixation, which is a very small portion of the radioactivity recovered in the dark-chamber epiphytes (Table 1).

Table 2 summarizes the proportion of the translocated ${ }^{14} \mathrm{C}$-carbon present in each compartment. As stated before, a smaller fraction of ${ }^{14} \mathrm{C}$-carbon was found in the dark-chamber epiphyte fraction when the Zostera marina leaves were scraped before incubation.

Table 2. Percent of total translocated ${ }^{14} \mathrm{C}$ recovered in Zostera marina epiphytes (dark chamber), leaf blades, $\mathrm{CO}_{2}$, and DOC. Radioactivity in each compartment was divided by the total amount of radioactivity (ca. $100,000 \mathrm{dpm}$ ) translocated from the illuminated chamber to the dark chamber

\begin{tabular}{|c|c|c|c|c|c|}
\hline $\begin{array}{l}\text { Compart- } \\
\text { ment }\end{array}$ & $\begin{array}{l}\text { Untr } \\
\text { Mediar }\end{array}$ & $\begin{array}{l}\text { eated } \\
\text { Range }\end{array}$ & $\begin{array}{r}\text { Pre-s } \\
\text { Mediar }\end{array}$ & $\begin{array}{l}\text { scraped } \\
\text { n Range }\end{array}$ & $\begin{array}{l}\text { Signifi- } \\
\text { cance }^{t}\end{array}$ \\
\hline Epiphytes & 10 & $5.4-39$ & 1.4 & $0.48-6.3$ & $p=0.05$ \\
\hline Leaf blade & 11 & $5.7-20$ & 6.0 & $1.8-7.8$ & $p=0.05$ \\
\hline $\mathrm{CO}_{2}$ & 78 & $52-84$ & 89 & $80-90$ & $p<0.05$ \\
\hline $\mathrm{DOC}$ & 6.3 & $5-16$ & 3.2 & $2.1-11$ & $p>0.05$ \\
\hline \multicolumn{6}{|c|}{$\begin{array}{l}\text { + Number of replicates listed in Table } 1 \text {. One-way Mann- } \\
\text { Whitney } U \text { test was used to examine differences between } \\
\text { untreated and pre-scraped leaves }\end{array}$} \\
\hline
\end{tabular}

Nearly $90 \%$ of the translocated ${ }^{14} \mathrm{C}$-carbon was present as ${ }^{14} \mathrm{CO}_{2}$. Since more ${ }^{14} \mathrm{CO}_{2}$ was present in the dark chamber when the leaves were scraped before the experiment, nearly all of the ${ }^{14} \mathrm{CO}_{2}$ appears to be from leaf respiration and not epiphyte respiration in the dark chamber

\section{Bacterial production supported by Zostera marina}

The microheterotrophic community on Zostera marina consists of bacteria, fungi and protozoans (Sieburth et al., 1974), but bacteria usually are the dominant microheterotrophs and the major organisms incorporating DOC. In order to calculate the proportion of bacterial growth and production supported directly by organic carbon released by leaves of $Z$. marina, we compared the rate of epiphytic bacterial uptake of leaf photosynthetically-fixed carbon and the rate of carbon incorporation from all sources available to epiphytic bacteria as estimated from the rate of bacterial production.

The rate of bacterial uptake of photosyntheticallyproduced organic carbon cannot be calculated by using the illuminated-chamber epiphytes because of epiphytic algal (primarily diatoms) fixation of ${ }^{14} \mathrm{CO}_{2}$. Rates cannot be calculated with the dark-chamber epiphytes alone since the specific activity of the organic carbon was not measured; there was no obvious method to measure directly this specific activity. Therefore, we assumed that the percent of ${ }^{14} \mathrm{C}$ in the dark-chamber epiphytes (Table 2) is the same percent incorporated by epiphytic bacteria in the illuminated chamber. The uptake rate of organic carbon released by Zostera marina leaves can be calculated then by multiplying the rate of leaf photosynthesis $(3.5 \mu \mathrm{gC}$ $\mathrm{h}^{-1} \mathrm{~cm}^{-2}$ ) by the proportion of ${ }^{14} \mathrm{C}$ found in the darkchamber epiphytes $(0.10)$. Therefore, the rate at which organic carbon was supplied to the epiphytic heterotrophs was approximately $0.35 \mu \mathrm{gC} \mathrm{h}{ }^{-1} \mathrm{~cm}^{-2}$.

The organic carbon provided by Zostera marina leaves $\left(0.35 \mu \mathrm{gC} \mathrm{h}^{-1} \mathrm{~cm}^{-2}\right)$ appears to be almost adequate to support the highest epiphytic bacterial production that we estimated $\left(0.4 \mu \mathrm{gC} \mathrm{h}^{-1} \mathrm{~cm}^{-2}\right)$. Bacterial production on $Z$. marina leaves was based on cell volumes and the incorporation of ${ }^{3} \mathrm{H}$-thymidine. Maximum rate of production was calculated by multiplying the highest thymidine incorporation rates by $4.5 \times 10^{9}$ cells nmole ${ }^{-1}$ (Kirchman et al., 1982), which is a high conversion factor compared to the original estimates of Fuhrman and Azam $(1980,1982)$. We estimate that the maximum rate of epiphytic bacterial production was $0.4 \mu \mathrm{gC} \mathrm{h}^{-1} \mathrm{~cm}^{-2}$, which was at the leaf tips. Thus, the $Z$. marina leaves appear to have been providing enough carbon for very high bacterial production and specific growth rates (doubling times of $1.5 \mathrm{~h}$; see below). Respiration was not included in the estimate of the photosynthetically-produced carbon that was incorporated by the epiphytes, nor in the estimate of the total amount of carbon taken up by the epiphytes (bacterial production). It was not possible to distinguish carbon respired by the epiphytes from that respired by $Z$. marina in the dark chamber. Likewise, bacterial production as estimated by thymidine incorporation measures the carbon necessary to synthesize new cell biomass only, and excludes the carbon oxidized for energy production and respired as $\mathrm{CO}_{2}$.

Gradients in bacterial abundance, biomass, and thymidine incorporation

Abundance, size and growth rates of bacteria were measured at the base, middle and tips of leaves of Zostera marina. There were significantly more bacteria 


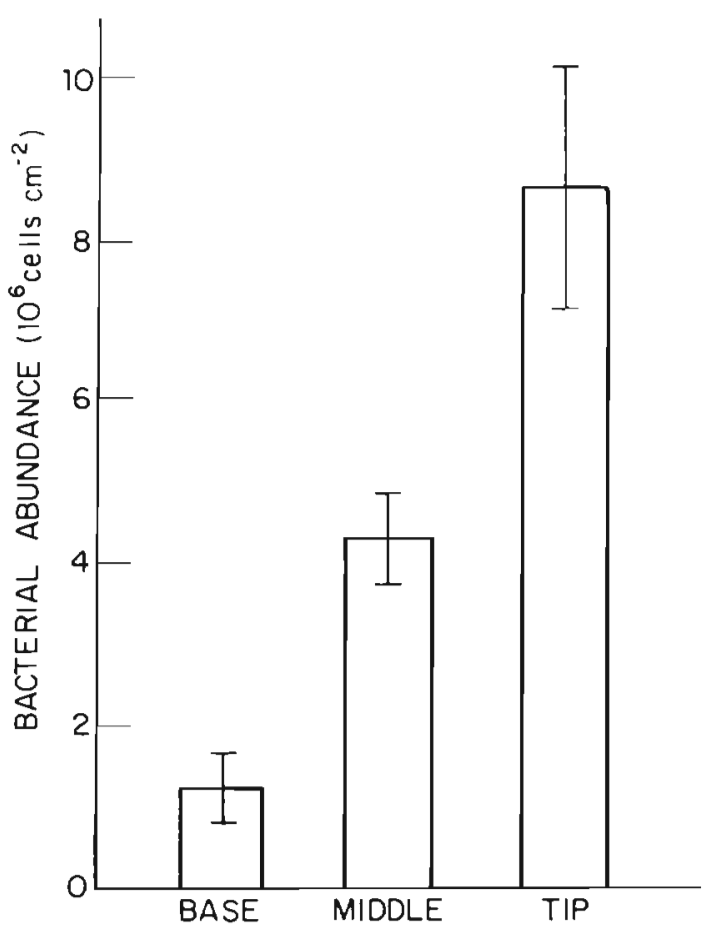

Fig. 2. Bacterial abundance along a Zostera marina leaf. Means and standard errors of 5 replicates for each leaf section are shown. Bacterial abundance increased significantly from leaf base to tip ( $\mathrm{p}<0.05_{i}$ Jonchkeere's test)

at the tip than at the base of the leaf $(\mathrm{p}<0.05$; Jonchkeere's test) (Fig. 2). The number of bacteria ranged from $8.5 \times 10^{6}$ cells $\mathrm{cm}^{-2}$ at the tip to $1.0 \times 10^{6}$ cells $\mathrm{cm}^{-2}$ at the base. The large variation (coefficient of variation of approximately $80 \%$ ) at any one part of the leaf seems to reflect real differences between leaves and not errors in counting bacteria. When 2 subsamples from the same homogenate were compared, the difference $(20 \%)$ was similar to other preparations for counting bacteria.

${ }^{3} \mathrm{H}$-thymidine incorporation, expressed as nmoles $\mathrm{h}^{-1} \mathrm{~cm}^{-2}$, increased significantly from the bases to the tips of leaves ( $p>0.05$; Jonchkeere's test) (Fig. 3). This gradient in incorporation can be accounted for by the gradient in bacterial numbers along Zostera marina leaves. There was no significant difference in the ${ }^{3} \mathrm{H}$ thymidine incorporation rate per cell at the 3 leaf locations ( $p>0.05$; Kruskal-Wallis test), but there was a significant correlation ( $p<0.01$; Spearman's rank correlation $r=0.78$ ) between the ${ }^{3} \mathrm{H}$-thymidine incorporation rate per unit area and the number of bacteria in each sample when results from all leaf sections were pooled (Fig. 4). Since these 2 parameters were measured independently, the differences between subsamples at one location and another on the leaf represent real variations in the epiphytic bacterial populations.

If the thymidine incorporation rates per cell are multiplied by a single conversion factor, bacterial growth

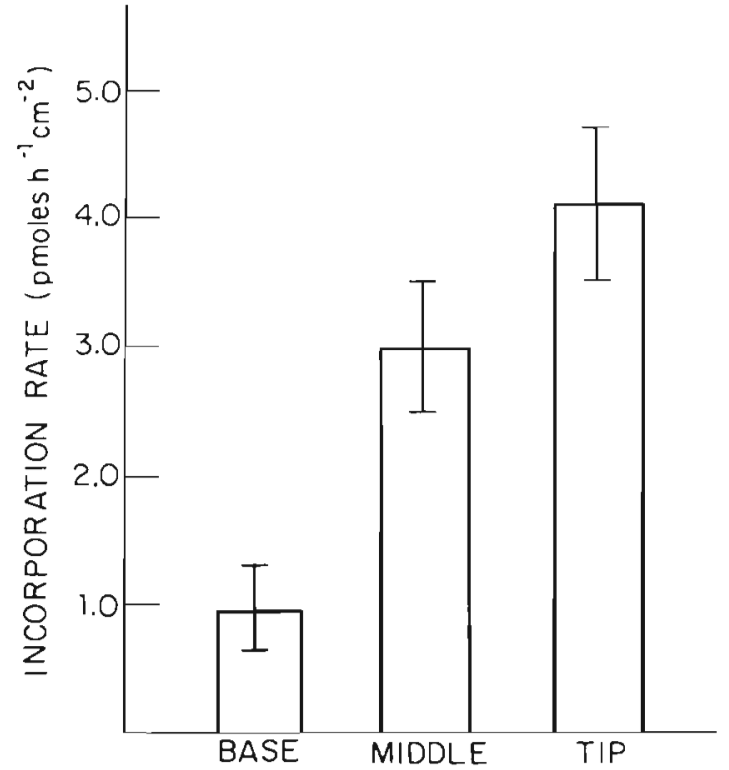

Fig. 3. Incorporation of ${ }^{3} \mathrm{H}$-thymidine into the TCA-insoluble fraction along a Zostera marina leaf. Means and standard errors of 5 replicates for each leaf section are shown. ${ }^{3} \mathrm{H}$ thymidine incorporation per unit area increased significantly from leaf base to tip ( $p<0.05$; Jonchkeere's test)

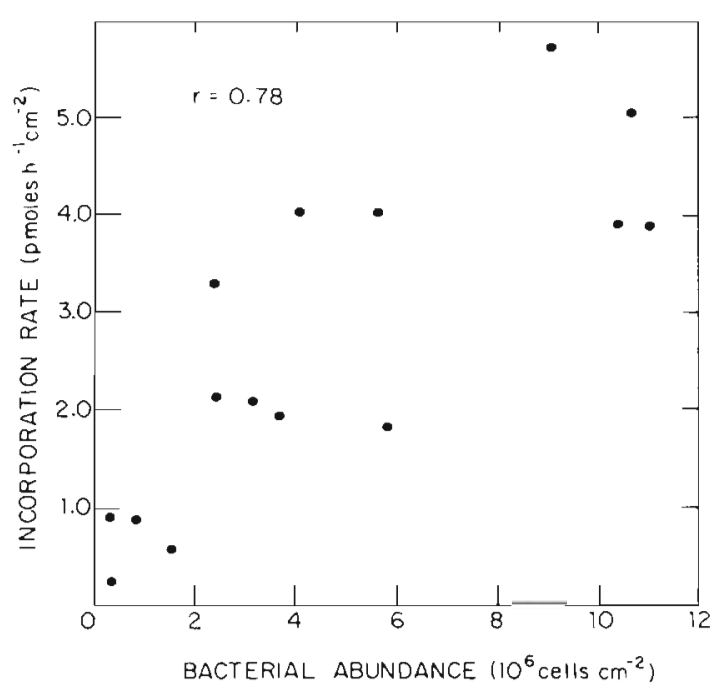

Fig. 4. Correlation between rate of ${ }^{3} \mathrm{H}$-thymidine incorporation and bacterial abundance on a Zostera marina leaf. The 5 subsamples from the 3 leaf sections were pooled together. Spearman's rank correlation coefficiency of $r=0.78$ is significant at the $\mathrm{p}<0.01$ level

rates appear to be similar at the base, middle and tip of the leaves. Using the highest conversion factor (see above), the doubling time of the bacteria was about $1.5 \mathrm{~h}$. Average size of a bacterial cell on each leaf section differed significantly $(p<0.05$; Kruskal-Wallis test), though there were no size gradients along the leaves (Table 3). 
Table 3. Cell volumes of bacterial epiphytes on Zostera marina leaves

\begin{tabular}{|ccc|}
\hline Leaf section & Mean & Error $^{\dagger}$ \\
\hline Tip & $0.33 \mu \mathrm{m}^{3}$ & $0.06 \mu \mathrm{m}^{3}$ \\
Middle & $0.49 \mu \mathrm{m}^{3}$ & $0.08 \mu \mathrm{m}^{3}$ \\
Base & $0.31 \mu \mathrm{m}^{3}$ & $0.03 \mu \mathrm{m}^{3}$ \\
& & \\
${ }^{\mathrm{t}} \mathrm{n}=125$ cells & & \\
\hline
\end{tabular}

\section{DISCUSSION}

The results presented here demonstrate that epiphytic microheterotrophs obtained organic compounds directly from Zostera marina photosynthesis as suggested by Smith and Penhale (1980). This carbon appears to support a substantial proportion of epiphytic bacterial production. Bacterial production and abundance showed significant gradients along the leaf axis from the bases to the tips. These results suggest that epiphytic bacterial production is tightly coupled to eelgrass production. Moriarty and Pollard (1982) found that epiphytic bacterial production was higher during the day than at night in seagrass beds of $Z$. capricorni, which also suggests a close relationship between the epiphytic bacterial community and $Z$. marina leaves.

Our estimate of the amount of carbon obtained from Zostera marina by the microheterotrophs was based on rates of primary production that were similar to the values of Penhale (1977). The proportion of fixed carbon incorporated by the epiphytic microheterotrophs $(10 \%)$ was much higher than the proportion of fixed carbon excreted as $\mathrm{DO}^{14} \mathrm{C}$, which Penhale and Smith (1977) estimated to be about $1 \%$. In our experiments the proportion of fixed carbon excreted as $\mathrm{DO}^{14} \mathrm{C}$ in the illuminated chambers was $2.2 \%$ (S. E. $=0.6 \%$ ), which is similar to the measurements of Penhale and Smith (1977). Our estimate of bacterial production, which was virtually equivalent to the amount of carbon obtained from $Z$. marina, is very high; the calculated generation time was $1.5 \mathrm{~h}$. Newell (1981) estimated that epiphytic bacteria on $Z$. marina had doubling times of $17.6 \mathrm{~h}$. A bacterial growth rate of $0.09 \mathrm{~d}^{-1}$ (or a doubling time of $8 \mathrm{~d}$ ) was calculated based on the difference between abundance at the tip and base, and on a leaf growth rate of $2 \mathrm{~cm} \mathrm{~d}^{-1}$ (W. Dennison, unpubl.) for the $50 \mathrm{~cm}$ leaves used in our experiment: $0.09 \mathrm{~d}^{-1}=\left[\ln \left(8.5 \times 10^{6} \mathrm{~cm}^{-2}\right)-\ln \left(1.0 \times 10^{6} \mathrm{~cm}^{-2}\right)\right] /$ $\left[50 \mathrm{~cm} / 2.0 \mathrm{~cm} \mathrm{~d} \mathrm{~d}^{-1}\right]$. Since our estimate of bacterial production based on ${ }^{3} \mathrm{H}$-thymidine incorporation is more likely too high rather than too low, the carbon originating directly from $Z$. marina leaves appears to be adequate to support growth of the epiphytic bacterial population.
Bacteria probably incorporated most of the organic ${ }^{14} \mathrm{C}$-carbon and ${ }^{3} \mathrm{H}$-methyl thymidine taken up by the epiphytic community. No viable fungal structures were found in leaf homogenates of Zostera marina (Newell, 1981). The algal half-saturation constants for all organics are much higher than the $5 \mathrm{nM}$ of ${ }^{3} \mathrm{H}$-thymidine we added, but perhaps they are in the range of DOC concentrations that the algal cell may experience on the leaf of $Z$. marina (Hellebust and Lewin, 1977). However, many studies have demonstrated that bacteria outcompete algae for DOC (Munro and Brock, 1968; Paerl and Goldman, 1972; Hoppe, 1976; MeyerReil, 1978).

Our estimates of bacterial cell volumes and abundances agree well with the results of Newell (1981) who examined Zostera marina from the Chesapeake Bay. He found that the average cell was $0.32 \mu \mathrm{m}^{3}$ while bacterial abundance ranged from 1 to $7 \times 10^{7} \mathrm{~cm}^{-2}$. The low values in bacterial abundance reported by Newell (1981) were from green plants, which are comparable with the plants we examined. Our estimates of bacterial abundance may be slightly lower than Newell's (1981) because of differences in habitats and the age of the leaf section sampled, although our homogenation of the leaf sections also was less thorough than Newell's (1981).

Bacteria on Zostera marina do not appear to be limited by energy or carbon, since the carbon made available by $Z$. marina to the epiphytic bacterial community was almost as great as the calculated bacterial production. Bacterial growth rates were the same along the entire leaf even though the absolute rate at which organic carbon was released by the leaf tips was probably higher than by the bases, since the absolute rate of excretion varies with the photosynthetic rate (Penhale and Smith, 1977) which increases by a factor of 2 from base to tip (Mazzella et al., 1980). A greater bacterial abundance was found at leaf tips rather than bases, probably because the tips are much older in this rhaminoid species; the plant grows at the base. Since bacterial production based on ${ }^{3} \mathrm{H}$-thymidine (gross production) was much higher than the observed difference in bacterial abundance from base to tip (net production), it appears that the size of the epiphytic bacterial population is limited by predation or the sloughing off of bacterial cells.

The importance of organic carbon originating directly from Zostera marina to the microheterotrophic community is underestimated when only DOC excretion is examined. That DOC is a small proportion of $Z$. marina production and has already been 'worked over' by the epiphytic bacterial community. The carbon used in the production of epiphytic bacterial biomass can be a large proportion of $Z$. marina production and may be passed on to higher trophic levels 
through predation by bacteriovores grazing either on epiphytic bacteria or on epiphytic bacteria that have become unattached.

Acknowledgements. We express our appreciation to John Hobbie for making facilities available for a portion of this research. L. Mazzella was supported by the Stazione Zoologia Napoli (Ischia, Italy). This research was conducted at the Marine Biological Laboratory, Woods Hole, MA., USA Research was supported by NOAA Sea Grant NA79AAD0091, ONR contract N00014-76-C-0042, and NSF grants DEB-792909 (a predoctoral grant awarded to D. L. K.), PCM79-006638, and PCM 78-10535.

\section{LITERATURE CITED}

Fuhrman, J. A., Azam, F. (1980). Bacterioplankton secondary estimates for coastal waters of British Columbia, Antarctica, and California. Appl. environ. Microbiol. 39: $1085-1095$

Fuhrman, J. A., Azam, F. (1982). Thymidine incorporation as a measure of heterotrophic bacterioplankton production in marine surface waters: evaluation and field results. Mar. Biol. 66: 109-120

Harlin, M. M. (1980). Seagrass epiphytes. In: Phillips, R. C., McRoy, C. P. (ed.) Handbook of seagrass biology. Garland STPM Press, New York, p. 117-151

Hellebust, J. A., Lewin, J. H. (1977). Heterotrophic nutrition. In: Werner, D. (ed.) The biology of diatoms. University of California Press, Berkeley, p. 169-197

Hobbie, J. E., Crawford, C. C. (1969). Respiration corrections for bacterial uptake of dissolved organic compounds in natural waters. Limnol. Oceanogr. 14: 528-532

Hobbie, J. E., Daley, R. J., Jasper, S. (1977). Use of Nuclepore filters for counting bacteria by fluorescent microscopy. Appl. environ. Microbiol. 33: 1225-1228

Hollander, M., Wolfe, D. A. (1973). Nonparametric statistical methods. John Wiley and Sons, New York

Hoppe, H. G. (1976). Determination and properties of actively metabolizing heterotrophic bacteria in the sea, investigated by means of microautoradiography. Mar. Biol. 36: 291-302

Kirchman, D., Ducklow, H. W., Mitchell, R. (1982). Estimates of bacterial production and growth based on changes in biomass and uptake rates. Appl. environ. Microbiol. 44: 1296-1307

Mazzella, L., Mauzerall, D., Lyman, H., Alberte, R. S. (1979). Photosynthetic characteristics of Zostera marina L. (eelgrass). Biol. Bull. mar. biol. Lab. Woods Hole 157: 382 Mazzella, L., Mauzerall, D., Alberte, R. S. (1980). Photo- synthetic light adaptation features of Zostera marina L. (eelgrass). Biol. Bull. mar. biol. Lab., Woods Hole 159: 500

Meyer-Reil, L. A. (1978). Autoradiography and epifluorescence microscopy combined for the determination of number and spectrum of actively metabolizing bacteria in natural waters. Appl. environ. Microbiol. 36: 506-512

McRoy, C. P., McMillan, C. (1977). Production ecology and physiology of seagrasses. In: McRoy, C. P., Helfferich, C. (ed.) Seagrass ecosystems, a scientific perspective. Marcel Dekker, Inc., New York, p. 83-87

McRoy, C. P., Goering, J. J. (1974). Nutrient transfer between the seagrass Zostera marina and its epiphytes. Nature, Lond. 248: 173-174

Moriarty, D. J. W., Pollard, P. C. (1982). Diel variation of bacterial productivity in seagrass (Zostera capricorni) beds measured by rate of thymidine incorporation into DNA. Mar. Biol. 72: 165-173

Munro, A. L. S., Brock, T. D. (1968). Distinction between bacterial and algal utilization of soluble substances in the sea. J. gen. Microbiol. 51: 35-42

Newell, S. Y. (1981). Fungi and bacteria in or on leaves of eelgrass (Zostera marina L.) from Chesapeake Bay. Appl. environ. Microbiol. 41: 1219-1224

Paerl, H. W., Goldman, C. R. (1972). Heterotrophic assays in the detection of water masses at Lake Tahoe, California. Limnol. Oceanogr. 17: 145-148

Penhale, P. A. (1977). Macrophyte-epiphyte biomass and productivity in an eelgrass (Zostera marina L.) community. J. exp. mar. Biol. Ecol. 26: 211-224

Penhale, P. A., Smith, W. O. Jr. (1977). Excretion of dissolved organic carbon by eelgrass (Zostera marina) and its epiphytes. Limnol. Oceanogr. 22: 400-407

Penhale, P. A., Thayer, G. W. (1980). Uptake and transfer of carbon and phosphorous by eelgrass (Zostera marina L.) and its epiphytes. J. exp. mar. Biol. Ecol. 42: 114-123

Phillips, R. C., MCRoy, C. P. (1980). Handbook of seagrass biology. Garland STPM Press, New York

Sieburth, J. McN, Brooks, R. D., Gessner, R. V., Thomas, C. D. (1974). Microbial colonization of marine plant surfaces as observed by scanning electron microscopy. In: Colwell, R. R., Morita, R. Y. (ed.) Effect of the ocean environment on microbial activities. University Park Press, Baltimore, p. 318-326

Smith, W. O., Penhale, P. A. (1980). The heterotrophic uptake of dissolved organic carbon by eelgrass (Zostera marina L.) and its epiphytes. J. exp. mar. Biol. Ecol. 48: 233-242

Sokal, R. R., Rohlf, F. J. (1969). Biometry. W. H. Freeman, San Francisco

Watson, F. W., Novitsky, T. J., Quinby, H. L., Valois, F. W. (1977). Determination of bacterial number and biomass in the marine environment. Appl. environ. Microbiol. 33: $940-946$ 